\title{
AJRC
}

Australia - Japan Research Centre

\section{What Types of Companies Have Female and Foreign Directors?*}

\section{AJRC Working Paper 04/2014 July 2014}

\section{Masayuki Morikawa}

Research Institute of Economy, Trade \& Industry (RIETI)

\section{Abstract}

This paper analyzes the determinants of the presence and the number of female and foreign directors among Japanese companies. First, listed and long-established companies, subsidiaries, and unionized companies tend not to have female directors. On the other hand, owner-managed companies are likely to have female directors and chief executive officers (CEOs). Company size and foreign shareholdings do not have significant relationships with the presence of female directors. Second, while some past studies in the United States and European countries find evidence of "tokenism," whereby female-led companies do not appoint additional females as directors, we do not find such evidence among Japanese companies. Third, while foreign-owned companies and companies engaged in overseas activities tend to have foreign directors, other company characteristics, such as size and listing status, do not have systematic relationships with the presence of foreign directors. 
*I would like to thank Masahisa Fujita, Ippei Fujiwara, Naomi Kodama, Yang Liu, Hiroyuki Nakata, Yasuhiko Yoshida and the seminar participants at RIETI for their helpful comments and suggestions. Any errors are my own. I would like to thank the Ministry of Economy, Trade and Industry for providing the micro data of the Basic Survey of Japanese Business Structure and Activities used in this study. This research is supported by the JSPS Grants-in-Aid for Scientific Research (B, 23330101).

\title{
Keywords
}

Female directors; Foreign directors; Diversity; Owner-managed company

\author{
JEL Classification
}

G32; J51; J71; M12; M51

\section{Suggested Citation}

Morikawa, M., 2014. What Types of Companies Have Female and Foreign Directors?, AJRC Working Paper No.4/2014, July. Australia-Japan Research Centre, Crawford School of Public Policy, The Australian National University.

This paper is also available at the RIETI website.

\section{Address for correspondence}

(E) ajrc@anu.edu.au

ISSN 07288409

ISBN 978-0-86413-004-4

The Australia-Japan Research Centre (AJRC) conducts research to explore and improve understanding of the economies and economic policy processes in Australia and Japan and both countries' strategic interests in the Asia Pacific economy.

The AJRC Working Paper Series aims to provide a forum for the exchange of topical research and contains the latest research and analysis on the Japanese economy, as well as the political economy, regional integration and trade. The views expressed in AJRC Working Papers are those of the individual authors and do not represent the views of the Australia-Japan Research Centre, the Crawford School, or the institutions to which authors are attached.

The Crawford School of Public Policy is the Australian National University's public policy school, serving and influencing Australia, Asia and the Pacific through advanced policy research, graduate and executive education, and policy impact. 


\section{What Types of Company Have Female and Foreign Directors?}

\section{Introduction}

Given the rapidly declining trend in population, the increase in female labor participation is regarded as one of the pillars of growth-promotion policy. The labor force of Japan is predicted to decrease by $0.8 \%$ on an annual basis until the year 2030, which will negatively contribute to the annual real GDP growth rate by $0.5 \%$. To mitigate this negative effect, the Japan Revitalization Strategy in 2013 set a target for the labor participation rate of females aged between 25 and 44 of $73 \%$ by 2020. Because the labor participation rate of females aged 25 to 44 in 2012 was $68 \%$, the target of $73 \%$ means 5 percentage points increase. ${ }^{1}$ Meanwhile Japan is known as its low level of female engagement in senior positions (e.g., OECD, 2012). ${ }^{2}$ To address this problem, the strategy encourages companies to employ more females in director and managerial positions: For example, the strategy states that listed companies should have at least one female director on the board.

According to the 2010 Population Census, the number of female directors is approximately 765 thousand (23.2\% of the total number of company directors) in Japan. Although the figure is far smaller than the number of male directors, the absolute number of more than 700 thousand is not negligible. To establish effective policy measures, it is essential for policymakers to have detailed evidence of the types of companies that employ female directors, but the subject has not been well researched. While it is not difficult to identify the female directors in public (listed) companies from the financial statements, the majority of the female directors are employed outside of the listed companies. Government official statistics covering small- and medium-sized companies do not have sufficient information about the attributes of company directors or the detailed company characteristics. For example, the Basic Survey of Japanese Business Structure and Activities (Ministry of Economy, Trade and Industry: METI) and the Financial Statements Statistics of Corporations (Ministry of Finance) do not have information about demographic characteristics such as the gender and age of managers and directors. The Economic Census for Business Activity and its predecessor the Establishment and Enterprise Census (Ministry of Internal Affairs and Communications: MIAC) collect information about the number of male/female paid directors. As a result, the basic characteristics of establishments

\footnotetext{
${ }^{1}$ The labor participation rate had increased by 6 percentage points from 2002 to 2012. The contribution of the stated increase in female labor force to GDP growth by 2020 is similar in magnitude with that of the past ten years.

${ }^{2}$ For example, according to the Global Gender Gap Index (World Economic Forum, 2013), Japan is ranked 105 th among the 136 countries.
} 
and companies such as the industry and number of female directors can be identified, but the information for the company characteristics is limited in these censuses. For example, These censuses do not have information about performance measures (e.g., profitability and productivity) and the governance structure (e.g., composition of shareholders). ${ }^{3}$

Given the globalizing trend in business activities, foreign directors also attract attention from the viewpoint of board diversity. Even in Japan, some large listed companies have recently started to appoint foreign nationals as chief executive officers (CEOs) or directors. However, the empirical studies on foreign directors are nearly nonexistent, partly because the government statistics generally do not have information regarding the nationality of directors.

Against this background, this paper, using an original company survey linked with the government statistics, presents empirical findings about the relationship between various company characteristics and the diversity of board structure. The purpose of this study is to identify what types of company have female/foreign directors in Japan. Specifically, we use the Survey of Corporate Management and Economic Policy (Research Institute of Economy, Trade and Industry: RIETI) and the Basic Survey of Japanese Business Structure and Activities (METI) for the fiscal year 2011. The gender of CEOs and the number of directors by gender and nationality (Japanese/non-Japanese) are available from the Survey of Corporate Management and Economic Policy. A variety of company characteristics such as industry, the number of employees, the ratio of foreign shareholdings, sales, and profit can be obtained from the Basic Survey of Japanese Business Structure and Activities. The number of sample companies in this matched data set is approximately 3,200. The detail of the data will be explained in Section 3.

To preview the major findings of this paper, first, the listed and long-established companies, subsidiaries of parents, and unionized companies are less likely to have female directors. On the other hand, owner-managed companies tend to have female directors and CEOs. Company age is negatively related to the presence of female directors: Females have a higher chance to become a director in younger companies. Second, while some past studies in the United States and European countries find evidence of "tokenism," whereby female-led companies do not appoint additional females as directors, we do not find such evidence among Japanese companies. Third, foreign directors are extremely rare. While foreign-owned companies and companies engaged in overseas activities tend to have foreign directors, other company characteristics, such as size and listing status, do not have systematic relationships with the presence of foreign directors.

The rest of this paper is structured as follows. Section 2 briefly reviews the literature. Section

\footnotetext{
${ }^{3}$ Siegel and Kodama (2011) partially overcome the data limitation by linking the data from the Establishment and Enterprise Census with the Basic Survey of Japanese Business Structure and Activities to analyze the relationship between the female director/manager and company performance.
} 
3 explains the method of analysis and the data used in this paper. Section 4 reports and interprets the results, and Section 5 concludes with policy implications.

\section{Literature Review}

Recently, the gender of CEOs and the board diversity have attracted attention from researchers, and a relatively large number of studies on the subject have been conducted in the field of labor economics and financial economics. ${ }^{4}$ Studies from the viewpoint of female labor mainly focus on the issue of the gender gap in compensation (e.g., Bell, 2005; Elkinawy and Stater, 2011; Bugeja et al., 2012) and discrimination in promotion by gender (Bertrand and Hallock, 2001; Elkinawy and Stater, 2011; Matsa and Miller, 2011; Gayle et al., 2012; Smith, et al., 2013; Conyon, 2014). ${ }^{5}$ On the other hand, the major interests of the studies in the field of finance and corporate governance are the effect of the female director on company performance (e.g., Carter et al., 2003; Wolfers, 2006; Adams and Ferreira, 2009; Gul et al., 2011; Ahern and Dittmar, 2012; Dezsö and Ross, 2012; Pathan and Faff, 2013; Matsa and Miller, 2013; Gregory-Smith et al., 2014) and the different management styles of female leaders (e.g., Gul et al., 2011; Huang and Kisgen, 2013; Matsa and Miller, 2014).

In these studies, the company characteristics that appoint female CEOs/directors are not necessarily the main focus of the analyses, but a few of them present descriptive statistics on the relationship between the company characteristics (industry, size, age, etc.) and the existence of female CEOs or the number of female directors. In terms of industry, past studies in the U.S. indicate that female CEOs and directors are likely to be in companies operating in the service (especially health and social services) and retail industries (Bertrand and Hallock, 2001; Wolfers, 2006; Gul et al., 2011; Bugeja et al., 2012; Huang and Kisgen, 2013). In terms of company size, studies in the U.S. generally find that the company size is positively associated with the number of female directors (Carter et al. 2003; Farrell and Hirsch, 2005; Adams and Ferreira, 2009; Gul et al., 2011), with the exception of Bertrand and Hallock (2001), which indicates that the size of companies with female directors is relatively small. Regarding female CEOs, Wolfers (2006) suggests that the size of the companies with female CEOs is somewhat smaller than the male counterparts. Studies reporting company age are scarce, but Gul et al. (2011) indicate that older companies are more likely to have female directors than younger companies in the sample of U.S. listed companies.

\footnotetext{
${ }^{4}$ Terjesen et al. (2009) present a comprehensive survey of this topic covering studies in sociology.

${ }^{5}$ It should be noted that as opposed to the majority of Japanese companies, for which the board of directors and executives of the companies are not separated, these are often separated in companies in the U.S. and certain European countries.
} 
While the main interest of the studies mentioned above is not the determinants of female directors, Farrell and Hersch (2005) and Parrotta and Smith (2013) are examples of studies that focus on the determinants for the appointment of female directors. Farrell and Hersch (2005) analyze the determinants and the effects of the appointment of females as new board members in the U.S. They indicate that institutional ownership and profitability (ROA) are positively related to the likelihood of adding a female to the board and that the percentage of females already on the board has a negative relationship with the likelihood of a female being added to the corporate board. Parrotta and Smith (2013), using a panel of Danish companies, analyze the determinants of the presence of females on the board of directors. They find that the companies with a female director on the board have a significantly lower probability of having another female on the board of directors. They interpret the result as evidence of the tokenism hypothesis.

In Japan, empirical studies on the relationship between the share of females in the workforce and company performance have been increasing recently (e.g., Kodama et al., 2005; Kawaguhi, 2007), but the analysis on female CEOs and directors has been scarce. A notable exception is Siegel and Kodama (2011). They construct a large data set by linking three government statistics - the Basic Survey of Japanese Business Structure and Activities (METI), the Establishment and Enterprise Census (MIAC), and the Basic Survey on Wage Structure (Ministry of Health, Labor and Welfare: MHLW) — and analyze the effects of female representation at various levels of the organization on the profitability of companies. They report that the presence and the number of female directors have a positive effect on profitability (ROA) within the manufacturing industry; however, such an effect cannot be observed in the service industry, in which the female participation in the workforce is relatively well advanced. According to the descriptive statistics of their study, the ratio of female directors is higher in the service industry compared to the manufacturing industry.

Regarding foreign directors, while the relationships between workforce diversity in nationality and the various measures of company performance have been actively studied (e.g., Parrotta et al. 2014a, b), analysis of the diversity at the board level has been limited. Oxelheima and Randøy (2003) and Masulis et al. (2012) are the rare examples. Oxelheima and Randøy (2003) analyze the effect of foreign (Anglo-American) board membership (AABM) on the Tobin's q for a sample of companies headquartered in Norway and Sweden. They find that the market value of companies having AABM is significantly higher than that of the companies without AABM. According to their descriptive statistics, several company characteristics such as foreign ownership, company size, company age, and board size are positively related to the presence of AABM. Masulis et al. (2012), using a sample of S\&P 1500 companies, analyze the effects of foreign independent directors (FIDs) on corporate governance and company 
performance. According to their results, approximately $13 \%$ of the sample companies have FIDs, and the companies with FIDs make more profitable cross-border acquisitions when the targets are the home regions of the FIDs. However, the overall performance (ROA, Tobin's q) of the companies with FIDs is significantly lower. With regard to the company characteristics associated with having FIDs, the company size, R\&D intensity, foreign sales ratio, and board size have a positive association with the existence of FIDs.

To summarize, although an increasing number of studies have presented several interesting findings about the company characteristics related to the appointment of female directors and CEOs, the stylized facts have not been established, and the studies on Japanese companies have been scarce. Furthermore, studies on the diversity in nationality at the board level have been rare. Evidence on the diversity of boards and its relationship with company characteristics in Japan will contribute to deepening our understandings of this issue. The advantages of this paper are the use of data covering a large number of both public (listed) and private (unlisted) companies and the inclusion of a wide range of variables related to corporate governance, such as the structure of shareholdings, the listing status, and the existence of labor unions.

\section{Data and Methodology}

The data used in this paper is from the Survey of Corporate Management and Economic Policy (RIETI) and is linked with the Basic Survey of Japanese Business Structure and Activities (METI) for the fiscal year 2011.

The Survey of Corporate Management and Economic Policy is an original survey conducted by the RIETI from December 2011 to February 2012. The questionnaire was sent to 15,500 Japanese companies representing the manufacturing and service industries, and a total of 3,444 companies responded to the survey. The survey questionnaires include the managerial objectives, composition of shareholders, and internal organizations. In this paper, we use questions about the gender of CEOs, the background of CEOs (promoted from within as an employee, founder of the company, a member of the founder's family, and other backgrounds), the number of directors including outside directors by gender and by nationality (Japanese or non-Japanese), listing status, whether the company is owner-managed, and the existence of a labor union. Among these survey items, some explanation about the "owner-managed" company may be necessary. In the survey, an "owner" is defined as "a founder, a member of the founding group, a descendant of a founder, and those who have a blood relation with the founder's family." An "owner-managed company" is "a company for which the owner is working as the chief executive or chairperson or a company in which the owner has substantial decision-making 
rights." This definition of the owner-managed company is similar to the family-controlled company in the literature.

The Basic Survey of Japanese Business Structure and Activities, an annual survey begun in 1992, is a representative survey of the government statistics on Japanese companies with 50 or more regular employees, including those engaged in mining, manufacturing, electricity and gas, wholesale, retail, and several service industries. The purpose of this survey is to capture a comprehensive picture of Japanese companies, including their basic financial information (sales, costs, profits, book value of capital, etc.), the number of employees, R\&D expenditure, IT usage, exports, and foreign direct investment. In this paper, we use the data from the survey for the fiscal year 2011 (conducted in 2012). The survey items used in this paper include the industry classification, foreign ownership ratio, existence of a parent company ${ }^{6}$, number of regular employees, year of establishment, holdings in foreign subsidiaries, exports, and profit. In addition, financial information including the sales, labor cost, and book value of tangible assets are used to estimate the total factor productivity (TFP).

We matched these two surveys at the company level to construct the final data set. The number of matched companies is 3,198, of which 1,546 companies (48.3\%) are classified in the manufacturing industry.

Using the data set, we analyze the determinants of female directors and CEOs. We estimate a Probit model for which the existence of female directors and female CEOs are used as the dependent dummy variables. In parallel, we employ a Tobit model to explain the ratio of female directors on the board. The reason for using the Tobit model is to avoid bias from censoring because a large number of companies do not have female directors as indicated later. The explanatory variables in the baseline estimations are the company size (log regular employees), age (years since the year of establishment), the industry dummies ( 1 digit), the foreign ownership ratio, the dummy for having a parent company, the dummy for a listed company, the owner-management dummy, the labor union dummy, and the total number of directors. For the Probit analysis, it is preferable to include the total number of directors as a control variable. The reason for this is that even if the directors are appointed randomly, companies with large board members are more likely to have at least one female on their board. For the Tobit model to explain the ratio of female directors, it is not essential to use this control variable. However, it is informative to include this variable, as past studies indicate that the total number of directors has a positive relationship with the number of female directors and the ratio of females on the board (Terjesen et al., 2009).

As mentioned in section 2, some studies suggest that companies with better performance

\footnotetext{
${ }^{6}$ The "parent company" is defined as a company holding more than $50 \%$ of the decision rights or a company having substantial controlling power.
} 
tend to appoint female directors (e.g., Farrell and Hersch, 2005), but other studies do not find a significant relationship between performance and the presence of females on the board (e.g., Gregory-Smith et al., 2014). We use the ROA and TFP as additional explanatory variables to investigate this relationship in Japan. The ROA is calculated as the current profit divided by the book value of tangible assets. The TFP is calculated in a nonparametric manner by the index number formula that uses a hypothetical representative company as reference. ${ }^{7}$ This calculation of TFP is frequently employed in productivity studies using data from the Basic Survey of Japanese Business Structure and Activities (e.g., Nishimura et al., 2005; Fukao and Kwon, 2006; Morikawa, 2010, 2013).

Further, we use a female CEO dummy as an additional explanatory variable in the estimations for the determinants of female directors. As mentioned in the previous section, the effect of female leaders on the appointment of another female on the board is an important research topic; however, the results have been divided into positive (e.g., Matsa and Miller, 2011) and negative (e.g., Farrell and Hersch, 2005; Parrotta and Smith, 2013). In these estimations, the dependent variables - the existence of a female director and the ratio of female directors - are constructed by excluding the female CEO herself.

We conduct similar estimations for the foreign directors. However, because our data set does not have information about the nationality of the CEOs, we restrict the analysis to the determinants of foreign directors. We use the indexes of globalization, specifically the dummies for FDI (holding foreign subsidiaries) and exports, as additional explanatory variables.

The major variables and the summary statistics are presented in Table 1 . The share of companies with female directors is $19.0 \%$, and the mean ratio of female directors is $5.4 \%$. The number of companies that have a female CEO is very small (1.2\%). The share of companies with foreign directors is only $1.3 \%$.

\section{Results}

\subsection{Female Directors}

We begin by presenting the distribution of the number of female directors in the sample companies (Table 2). The majority (81\%) of companies has no female director, $14.3 \%$ have one female director, and $4.7 \%$ have two or more female directors.

\footnotetext{
${ }^{7}$ The value added is used as the output, and labor (hours) and tangible capital stock are used as inputs. The input and output of a hypothetical representative firm are calculated as the geometric means of those of all firms, and the cost shares of labor and capital are calculated as the arithmetic means.
} 
Column (1) of Table 3 presents the Probit estimation results on the determinants for the presence of female directors. The figures are the marginal effects of the explanatory variables with the robust standard errors corrected for heteroskedsticity in parentheses. Owner-managed companies tend to have females on their board, and the magnitude is economically significant: Owner-managed companies are $15.8 \%$ more likely to have a female director. On the other hand, companies controlled by a parent company, listed companies, and companies with labor unions are less likely to have a female director on the board (marginal effects are $-12.8 \%,-10.3 \%$, and $-8.1 \%$, respectively). The coefficient for company size is negative but statistically insignificant, meaning that the larger companies do not necessarily tend to have female directors on the board. Studies in the U.S. generally find a positive association between company size and the likelihood of the presence of a female on the board (Carter et al. 2003; Farrell and Hirsch, 2005; Adams and Ferreira, 2009; Gul et al., 2011); however, the result for the Japanese companies is different. Even when we restrict the sample to listed companies, the coefficient for company size is insignificant. ${ }^{8}$ The coefficient for company age is negative and significant, indicating, other things being equal, that younger companies are more likely to have female directors. One standard deviation (19.5 years) younger in age is associated with a $2.8 \%$ higher probability of having a female on the board. In the U.S., Gul et al. (2011), for example, report that the mean age of companies with female directors is higher than companies without female directors, but the result here is the opposite. Even when we restrict the sample to listed companies, the coefficient for company age is negative and significant at the $5 \%$ level. The coefficient for the ratio of foreign shareholdings is insignificant, meaning that the probability of having female directors is unaffected by foreign ownership. As expected, the coefficient for the number of total directors on the board is positive and significant; that is, after controlling for company size and other characteristics, the larger the board size, the higher is the probability of having at least one female director. While the coefficients for industry dummies are not reported in the table, the dummies for retail industry and the information and communications industry are positive and significant (the manufacturing industry is the reference).

The Tobit estimation result for which the ratio of female directors is used as the dependent variable is reported in column (2) of Table 3. The sign of the estimated coefficients for owner-management, parent company, listed company, labor union, and company age are the same as the results of the Probit estimation, and all of them are statistically significant at the $1 \%$ level. The coefficients for company size and foreign ownership are both insignificant, which is the same as the Probit estimation results.

The Probit estimation results for the determinants of a female CEO are presented in column (3) of Table 3. Because companies with female CEOs are rare, the majority of the variables are

${ }^{8}$ The number of listed companies in our sample is 206. 
insignificant. However, the coefficient for owner-management is positive and significant at the $1 \%$ level. The coefficient for company age is negative and significant at the $10 \%$ level, suggesting that after controlling for the other company characteristics, female CEOs are more likely to be in relatively young companies.

Studies outside Japan generally indicate that better performing companies tend to appoint female directors to their board (e.g., Adams and Ferreira, 2009; Gul et al., 2011; Huang and Kisgen, 2013). We analyze this point using the ROA and TFP as additional dependent variables (not reported in the table). When adding the ROA as the performance measure, the coefficient is positive and insignificant. On the other hand, when we add the TFP as the explanatory variable, the coefficient for TFP is negative and significant at the $5 \%$ level for the presence and the number of female directors. These results suggest that in Japan, companies that perform well do not necessarily appoint female directors to the board.

As referenced in section 2, some studies in the U.S. and Europe present evidence supporting the tokenism hypothesis that companies with a female director on the board have a significantly lower probability of appointing another female to the board of directors (Farrell and Hersch, 2005; Parrotta and Smith, 2013; Smith et al., 2013). Furthermore, Smith et al. (2013) indicate that a female chairman on the board of directors has a negative effect on the chances for the promotion of a female to CEO. On the other hand, Matsa and Miller (2011) and Elkinawy and Stater (2011) find a positive spillover effect of the presence of female board members on the probability of having female top executives among the listed U.S. companies. To address this issue, we use the female CEO dummy as an additional explanatory variable in the estimations for the presence and the ratio of female directors. In these estimations, the dependent variables are constructed by excluding the female CEO herself. The coefficients for the other explanatory variables are not fundamentally affected by the inclusion of this variable. The coefficients for female CEO are negative and insignificant for both the Probit and Tobit models (Table 4). That is, among Japanese companies, we do not find strong evidence of the tokenism exhibited by female-led companies not appointing additional females as directors.

In the empirical studies of corporate governance, reverse causality is often a difficult problem to resolve. ${ }^{9}$ However, the purpose of this paper is to identify the company characteristics that determine the presence of female directors. Although we cannot completely eliminate the possibility of reverse causality, it is unlikely that the presence of female directors causes the fundamental company characteristics such as size, age, and composition of shareholdings.

Table 5 is the tabulation of the background of CEOs by gender. The data are taken from the

\footnotetext{
${ }^{9}$ Roberts and Whited (2013) survey the problems of endogeneity related to the empirical studies on corporate governance.
} 
Survey of Corporate Management and Economic Policy. The questionnaire for the survey inquired about the background of the CEOs using the following choices: 1) employee (clerical), 2) employee (engineering), 3) founder, 4) founder's family, 5) parent company, 6) financial companies, and 7) others. We combine choices 1) and 2) for the category "employee," and choices 5), 6) and 7) for the category "others." It is obvious that the dominant background of female CEOs is founder's family (74.4\%), and the percentage of CEOs promoted from the employees is relatively small (9.3\%).

To summarize, the results presented above indicate that it is difficult for females to become directors or CEOs in listed long-established companies and their subsidiaries, suggesting the existence of the "glass ceiling." On the other hand, in the owner-managed companies, those from the founder's family including spouse and daughter have a greater chance to become director, and in some cases they are promoted to CEO through the succession among family members. In addition, younger companies provide greater opportunities for females to have roles on the board. Recent studies in the field of corporate governance have indicated the distinct characteristics of family-controlled companies compared with the companies characterized by dispersed ownership (Morck et al. 2005; Mehrotra and Morck, 2013, for surveys). ${ }^{10}$ The findings of this paper confirm the distinct nature of family-controlled companies in the context of female representation.

\subsection{Foreign Directors}

In parallel with female representation on the board, that of foreign nationals also attracts attention from the viewpoint of greater board diversity. Table 2 displays the distribution of the number of foreign directors in the sample companies. The media reports the appointments of non-Japanese as CEOs or directors to large listed companies, but in our sample of a large number of unlisted companies, the vast majority of companies (98.7\%) do not have a foreign director on the board.

Columns (1) and (3) of Table 7 present the baseline Probit and Tobit estimation results to explain the presence and the ratio of foreign directors. For both estimations, the coefficients for the ratio of foreign shareholding are positive and highly significant: Foreign ownership has a positive association with the presence of foreign directors. However, other variables including the company size and owner-management dummy are generally insignificant, with the exception of the board size. Apart from the foreign-owned companies, listed large companies do

${ }^{10}$ Saito (2008), Mehrotra, et al. (2013), and Morikawa (2013) are examples of the empirical studies on family-controlled companies in Japan. 
not necessarily use non-natives as board members. ${ }^{11}$

Columns (2) and (4) of Table 7 are the results reflecting the use of dummies for FDI (holding foreign subsidiaries) and exporting as additional explanatory variables. The coefficients for FDI are positive and significant at the 5\% level in both the Probit and Tobit estimations, and the coefficients for exporting have a positive association (the significance level is $10 \%)$ with the presence of foreign directors. These results suggest that the expansion of overseas activities contributes positively to greater diversity in the nationality of boards. When adding the ROA or TFP as explanatory variables, the coefficients for these performance measures are insignificant (not reported in the table), indicating that profitability and productivity are not related to the presence of foreign directors.

\section{Conclusion}

This paper, using a linked data set of more than 3,000 Japanese companies in the fiscal year 2011 from the Survey of Corporate Management and Economic Policy and the Basic Survey of Japanese Business Structure and Activities, empirically analyzes the determinants of the presence and the number of female and foreign directors among Japanese companies. The major findings can be summarized as follows. First, the likelihood of having a female director is smaller for listed and long-established companies, subsidiaries, and unionized companies. On the other hand, owner-managed companies are more likely to have female directors and female CEOs. Second, we do not find evidence of tokenism - whereby female-led companies not appointing additional females as directors - among Japanese companies. Third, foreign directors are extremely rare. While foreign-owned companies and companies engaged in overseas activities tend to have foreign directors, other company characteristics, such as size and listing status, do not exhibit systematic relationships with the presence of foreign directors.

Notwithstanding the increasing pressure from the public and the institutional investors to diversify the composition of board members, the boards of the listed large companies do not necessarily exhibit greater diversity. In contrast, the boards of owner-managed companies and young companies are more likely to be diverse in gender. Based on the findings of this paper, to increase the number of female executives and directors substantially, it is necessary to take comprehensive approaches without being limited to measures targeted to long-term employees at listed large companies. "The Japan Revitalization Strategy" refers to the creation of new businesses as an important challenge, aiming to achieve a business startup rate of $10 \%$. Although this program is not mentioned in the context of female directors, new businesses

${ }^{11}$ Even if we restrict the sample to listed companies, both size and age are insignificant. 
started by females would directly lead to an increase in the number of female directors. In addition, even for new businesses started by males, young and growing companies are likely to appoint females as directors. The strategy also states that the government will "encourage new businesses by females." Policies to enhance female willingness to start new businesses will have a consequent effect on increasing the number of female CEOs and directors. ${ }^{12}$ With regard to board diversity in nationality, policies to increase inward FDI and to expand the overseas businesses of domestic companies will contribute to board diversity. The fact that board size has a positive association with the presence of female and foreign directors suggests that an increase in the board size can be an option to diversify the composition of the board. Earlier studies suggest that board size has a negative association with the market valuation of a company (e.g., Yermack, 1996), but more recent studies indicate that the optimal board size depends on various business characteristics and that the reduction of the board size does not assure better company performance (e.g., Boone et al., 2007; Coles et al., 2008; Linck et al., 2008; Wintoki et al., 2012). For some companies, the benefit of diversifying the board composition may outweigh the cost of increasing the board members. In such cases, appointing female/foreign directors in parallel with expanding the board size is a practical solution.

\footnotetext{
${ }^{12}$ Koellinger et al. (2013), using population surveys in 17 countries including Japan, find that the lower rate of female business ownership is primarily due to their lower propensity to start businesses. Higuchi and Kodama (2014), using the panel data for start-up businesses in Japan, find that the probability of female-owned start-ups obtaining loans is not significantly different with that of male-owned ones but that females tend to give up on obtaining loans before applying.
} 


\section{References}

Adams, Renée B. and Daniel Ferreira (2009), "Women in the Boardroom and Their Impact on Governance and Performance," Journal of Financial Economics, Vol. 94, No. 2, pp. 291-309.

Ahern, Kenneth R. and Amy K. Dittmar (2012), "The Changing of the Boards: The Impact on Firm Valuation of Mandated Female Board Representation,” Quarterly Journal of Economics, Vol. 127, No. 1, pp. 137-197.

Bell, Linda A. (2005), “Women-Led Firms and the Gender Gap in Top Executive Jobs,” IZA Discussion Paper, No. 1689.

Bertrand, Marianne and Kevin F. Hallock (2001), “The Gender Gap in Top Corporate Jobs,” Industrial and Labor Relations Review, Vol. 55, No. 1, pp. 3-21.

Boone, Audra L., Laura Casares Field, Jonathan M. Karpoff, and Charu G. Raheja (2007), "The Determinants of Corporate Board Size and Composition: An Empirical Analysis," Journal of Financial Economics, Vol. 85, No. 1, pp. 66-101.

Bugeja, Martin, Zoltan P. Matolcsy, and Helen Spiropoulos (2012), “Is There a Gender Gap in CEO Compensation?” Journal of Corporate Finance, Vol. 18, No. 4, pp. 849-859.

Carter, David A., Betty J. Simkins, and W. Gary Simpson (2003), “Corporate Governance, Board Diversity, and Firm Value,” The Financial Review, Vol. 38, No. 1, pp. 33-53.

Coles, Jeffrey C., Naveen D. Daniel, and Lalitha Naveen (2008), "Boards: Does One Size Fit All?” Journal of Financial Economics, Vol. 87, No. 2, pp. 329-356.

Conyon, Martin J. (2014), "Executive Compensation and Board Governance in US Firms,” Economic Journal, Vol. 124, February, pp. F60-F89.

Dezsö, Cristian L. and David Gaddis Ross (2012), "Does Female Representation in Top Management Improve Firm Performance? A Panel Data Investigation,” Strategic Management Journal, Vol. 33, No. 9, pp. 1072-1089.

Elkinawy, Susan and Mark Stater (2011), “Gender Differences in Executive Compensation: Variation with Board Gender Composition and Time,” Journal of Economics and Business, Vol. 63, No. 1, pp. 23-45.

Farrell, Kathleen A. and Philip L. Hersch (2005), “Additions to Corporate Boards: The Effect of Gender,” Journal of Corporate Finance, Vol. 11, Nos. 1-2, pp.85-106.

Fukao, Kyoji and Hyeog Ug Kwon (2006), “Why Did Japan’s TFP Growth Slow Down in the Lost Decade? An Empirical Analysis Based on Firm-Level Data of Manufacturing Firms,” Japanese Economic Review, Vol. 57, No. 2, pp. 195-228.

Gayle, George-Levi, Limor Golan, and Robert A. Miller (2012), “Gender Differences in Executive Compensation and Job Mobility,” Journal of Labor Economics, Vol. 30, No. 4, 
pp. 829-871.

Gregory-Smith, Ian, Brian G. M. Main, and Charles A. O’Reilly III (2014), “Appointments, Pay and Performance in UK Boardrooms by Gender," Economic Journal, Vol. 124, February, pp. F109-F128.

Gul, Ferdinand A., Bin Srinidhi, and Anthony C. Ng (2011), "Does Board Gender Diversity Improve the Informativeness of Stock Prices?” Journal of Accounting and Economics, Vol. 51, No. 3, pp. 314-338.

Higuchi, Yoshio and Naomi Kodama (2014), "Do Women-owned Start-ups Have a Lower Probability of Obtaining Loans? An Empirical Analysis Using Panel Data from Japan,” RIETI Discussion Paper, 14-J-015. (in Japanese)

Huang, Jiekun and Darren J. Kisgen (2013), "Gender and Corporate Finance: Are Male Executives Overconfident Relative to Female Executives?” Journal of Financial Economics, Vol. 108, No. 3, pp. 822-839.

Johnston, David W. and Wang-Sheng Lee (2012), “Climbing the Job Ladder: New Evidence of Gender Inequality,” Industrial Relations, Vol. 51, No. 1, pp. 129-151.

Kawaguchi, Daiji (2007), “A Market Test for Sex Discrimination: Evidence from Japanese Firm-Level Data.” International Journal of Industrial Organization, Vol. 25, No. 3, pp. 441-460.

Kodama, Naomi, Kazuhiko Odaki, and Yoko Takahashi (2005), "Female Employment and Corporate Performance,” JCER Economic Journal, No. 52, pp. 1-18. (in Japanese)

Koellinger, Philipp, Maria Minniti, and Christian Schade (2013), "Gender Differences in Entrepreneurial Propensity,” Oxford Bulletin of Economics and Statistics, Vol. 75, No. 2, pp. 213-234.

Linck, James S., Jeffry M. Netter, and Tina Yang (2008), “The Determinants of Board Structure,” Journal of Financial Economics, Vol. 87, No. 2, pp. 308-328.

Masulis, Ronald W., Cong Wang, and Fei Xie (2012), "Globalizing the Boardroom: The Effects of Foreign Directors on Corporate Governance and Firm Performance,” Journal of Accounting and Economics, Vol. 53, No. 3, pp. 527-554.

Matsa, David A. and Amalia R. Miller (2011), “Chipping away at the Glass Ceiling: Gender Spillovers in Corporate Leadership,” American Economic Review, Vol. 101, No. 3, pp. 635-639.

Matsa, David A. and Amalia R. Miller (2013), “A Female Style in Corporate Leadership? Evidence from Quotas,” American Economic Journal: Applied Economics, Vol. 5, No. 3, pp. 136-169.

Matsa, David A. and Amalia R. Miller (2014), "Workforce Reductions at Women-Owned Businesses in the United States,” Industrial and Labor Relations Review, Vol. 67, No. 2, pp. 
422-452.

Mehrotra, Vikas and Randall Morck (2013), “Entrepreneurship and the Family Firm,” in George M. Constantinides, Milton Harris and Rene M. Stulz eds. Handbook of the Economics of Finance, Vol. 2, Part. A, Amsterdam: Elsevier, Ch. 9, pp. 649-681.

Mehrotra, Vikas, Randall Morck, Jungwoon Shim, and Yupana Wiwattanakaantang (2013), "Adoptive Expectations: Rising Sons in Japanese Family Firms," Journal of Financial Economics, Vol. 108, No. 3, pp. 840-854.

Morck, Randall, Daniel Wolfenzon, and Bernard Yeung (2005), “Corporate Governance, Economic Entrenchment and Growth,” Journal of Economic Literature, Vol. 43, No. 3, pp. 655-720.

Morikawa, Masayuki (2010), "Labor Unions and Productivity: An Empirical Analysis Using Japanese Firm-Level Data,” Labour Economics, Vol. 17, No. 6, pp. 1030-1037.

Morikawa, Masayuki (2013), “Productivity and Survival of Family Firms in Japan,” Journal of Economics and Business, Vol. 70, November-December, pp. 111-125.

Nishimura, Kiyohiko G., Takanobu Nakajima, and Kozo Kiyota (2005), "Does the Natural Selection Mechanism Still Work in Severe Recessions? Examination of the Japanese Economy in the 1990s," Journal of Economic Behavior and Organization, Vol. 58, No. 1, pp. 53-78.

OECD (2012), Closing the Gender Gap, Paris: OECD Publishing.

Oxelheima, Lars and Trond Randøy (2003), “The Impact of Foreign Board Membership on Firm Value,” Journal of Banking and Finance, Vol. 27, No. 12, pp. 2369-2392.

Parrotta, Pierpaolo and Nina Smith (2013), "Why So Few Women on Boards of Directors? Empirical Evidence from Danish Companies 1997-2007,” IZA Discussion Paper, No. 7678. Parrotta, Pierpaolo, Dario Pozzoli, and Mariola Pytlikova (2014a), “Labor Diversity and Firm Productivity,” European Economic Review, Vol. 66, February, pp. 144-179.

Parrotta, Pierpaolo, Dario Pozzoli, and Mariola Pytlikova (2014b), "The Nexus between Labor Diversity and Firm's Innovation,” Journal of Population Economics, Vol. 27, No. 2, pp. 303-364.

Roberts, Michael R. and Toni M. Whited (2013), "Endogeneity in Empirical Corporate Finance," in George M. Constantinides, Milton Harris and Rene M. Stulz eds. Handbook of the Economics of Finance, Volume 2, Part A, Amsterdam: Elsevier, Ch. 7, pp. 493-572.

Saito, Takuji (2008), “Family Firms and Firm Performance: Evidence from Japan,” Journal of the Japanese and International Economies, Vol. 22, No. 4, pp. 620-646.

Siegel, Jordan and Naomi Kodama (2011), "Labor Market Gender Disparity and Corporate Performance in Japan,” RIETI Discussion Paper, 11-E-075.

Smith, Nina, Valdemar Smith, and Mette Verner (2013), "Why Are So Few Females 
Promoted into CEO and Vice President Positions? Danish Empirical Evidence, 1997-2007,” Industrial and Labor Relations Review, Vol. 66, No. 2, pp. 380-408.

Terjesen, Siri, Ruth Sealy, and Val Singh (2009), "Women Directors on Corporate Boards: A Review and Research Agenda," Corporate Governance: An International Review, Vol. 17, No. 3, pp. 320-337.

Wintoki, M. Babajide, James S. Linck, and Jeffry M. Netter (2012), "Endogeneity and the Dynamics of Internal Corporate Governance,” Journal of Financial Economics, Vol. 105, No. 3, pp. 581-606.

Wolfers, Justin (2006), "Diagnosing Discrimination: Stock Returns and CEO Gender," Journal of the European Economic Association, Vol. 4, Nos. 2-3, pp. 531-541.

World Economic Forum (2013), The Global Gender Gap Report 2013.

Yermack, David (1996), “A Higher Market Valuation of Companies with a Small Board of Directors,” Journal of Financial Economics, Vol. 40, No. 2, pp. 185-211. 
Table 1 Summary Statistics

\begin{tabular}{|l|r|r|r|r|r|}
\hline & Obs & Mean & Std. Dev. & Min & Max \\
\hline Female director (dummy) & 3,390 & 0.190 & 0.393 & 0 & 1 \\
\hline Ratio of female directors & 3,389 & 0.054 & 0.128 & 0 & 1 \\
\hline Female CEO (dummy) & 3,444 & 0.012 & 0.111 & 0 & 1 \\
\hline Foreign director (dummy) & 3,444 & 0.012 & 0.111 & 0 & 1 \\
\hline Ratio of foreign directors & 3,389 & 0.005 & 0.057 & 0 & 1 \\
\hline Company size (log employee) & 3,198 & 5.245 & 1.031 & 3.912 & 11.249 \\
\hline Company age & 3,198 & 43.726 & 19.456 & 0 & 167 \\
\hline Ratio of foreign shareholdings & 3,198 & 1.377 & 9.714 & 0 & 100 \\
\hline Subsidiary (dummy) & 3,444 & 0.329 & 0.470 & 0 & 1 \\
\hline Listed company (dummy) & 3,412 & 0.060 & 0.238 & 0 & 1 \\
\hline Owner-managed (dummy) & 3,392 & 0.569 & 0.495 & 0 & 1 \\
\hline Labor union (dummy) & 3,384 & 0.297 & 0.457 & 0 & 1 \\
\hline Number of directors & 3,389 & 5.272 & 2.638 & 1 & 25 \\
\hline
\end{tabular}

Note: The figures are calculated from the Survey of Corporate Management and Economic Policy (RIETI).

Table 2 Distribution of the Number of Female Directors

\begin{tabular}{|l|r|r|}
\hline & Companies & $\%$ \\
\hline 0 & 2,745 & $81.0 \%$ \\
\hline 1 & 484 & $14.3 \%$ \\
\hline 2 & 126 & $3.7 \%$ \\
\hline 3 & 22 & $0.7 \%$ \\
\hline 4 & 9 & $0.3 \%$ \\
\hline 5 or more & 4 & $0.1 \%$ \\
\hline Total & 3,390 & $100.0 \%$ \\
\hline
\end{tabular}

Note: The figures are calculated from the Survey of Corporate Management and Economic Policy (RIETI). 
Table 3 Female Directors/CEO and Company Characteristics

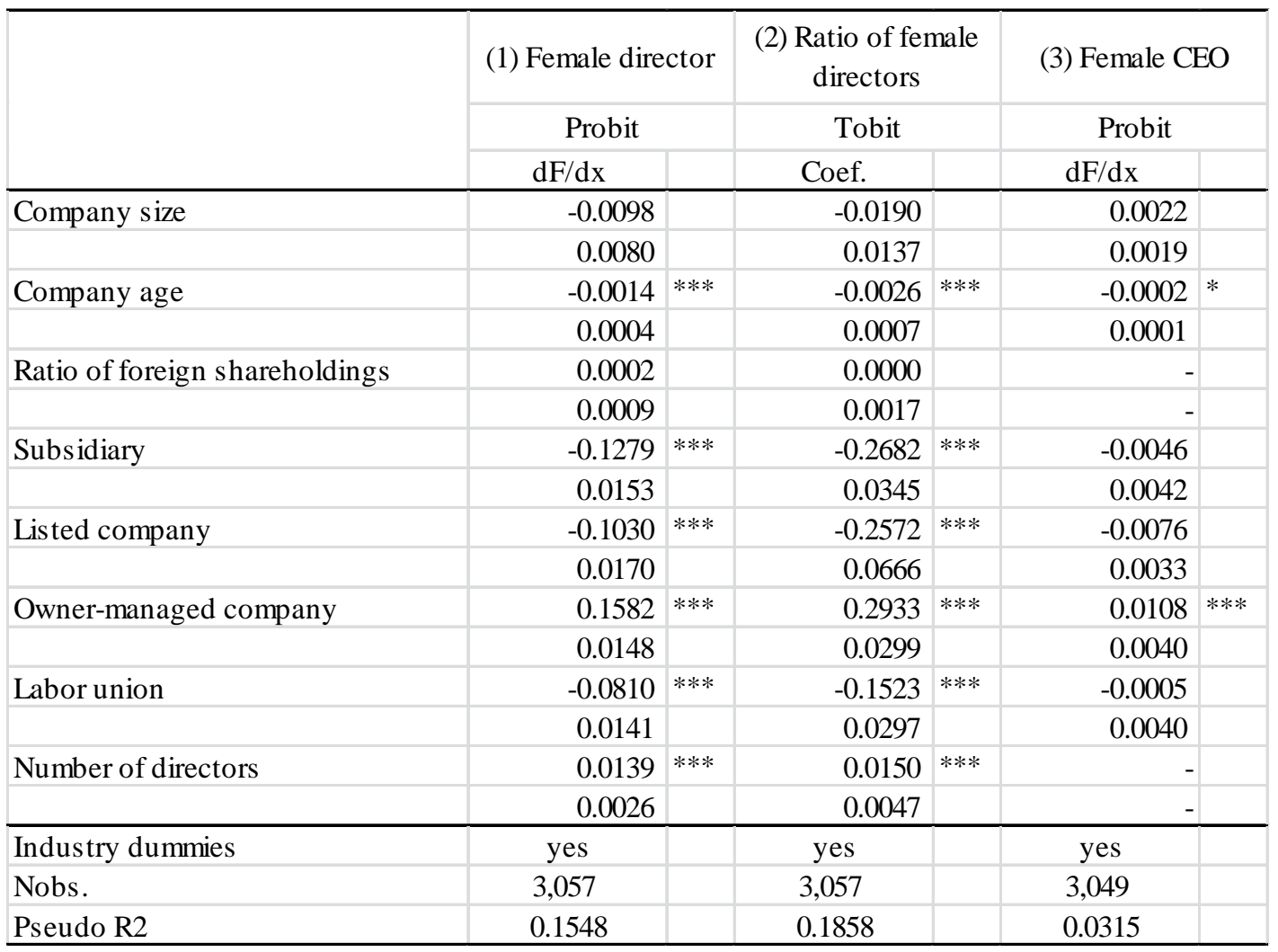

Notes: Estimated from data from the Survey of Corporate Management and Economic Policy (RIETI) linked with the Basic Survey of Japanese Business Structure and Activities METI). Probit and Tobit estimates with robust standard errors in parentheses. $* * *, * *$, and * indicate statistical significance at the $1 \%, 5 \%$, and $10 \%$ levels, respectively. 
Table 4 Female CEO and Other Female Directors

\begin{tabular}{|c|c|c|c|c|}
\hline & \multirow{2}{*}{\multicolumn{2}{|c|}{$\begin{array}{c}\begin{array}{l}\text { (1) Female director } \\
\text { (except CEO) }\end{array} \\
\text { Probit } \\
\end{array}$}} & \multirow{2}{*}{\multicolumn{2}{|c|}{$\begin{array}{c}\text { (2) Ratio of female } \\
\text { directors (except CEO) } \\
\text { Tobit }\end{array}$}} \\
\hline & & & & \\
\hline & $\mathrm{dF} / \mathrm{dx}$ & & Coef. & \\
\hline \multirow[t]{2}{*}{ Company size } & -0.0157 & $* *$ & -0.0340 & $*$ \\
\hline & 0.0076 & & 0.0196 & \\
\hline \multirow[t]{2}{*}{ Company age } & -0.0013 & $* * *$ & -0.0033 & $* * *$ \\
\hline & 0.0004 & & 0.0010 & \\
\hline \multirow[t]{2}{*}{ Ratio of foreign shareholdings } & 0.0002 & & 0.0000 & \\
\hline & 0.0009 & & 0.0024 & \\
\hline \multirow[t]{2}{*}{ Subsidiary } & -0.1233 & $* * *$ & -0.3871 & $* * *$ \\
\hline & 0.0146 & & 0.0508 & \\
\hline \multirow[t]{2}{*}{ Listed company } & -0.0870 & $* * *$ & -0.3064 & $* * *$ \\
\hline & 0.0176 & & 0.0906 & \\
\hline \multirow[t]{2}{*}{ Owner-managed company } & 0.1480 & $* * *$ & 0.3997 & $* * *$ \\
\hline & 0.0143 & & 0.0432 & \\
\hline \multirow[t]{2}{*}{ Labor union } & -0.0799 & $* * *$ & -0.2246 & $* * *$ \\
\hline & 0.0134 & & 0.0427 & \\
\hline \multirow[t]{2}{*}{ Number of directors } & 0.0144 & $* * *$ & 0.0094 & \\
\hline & 0.0025 & & 0.0075 & \\
\hline \multirow[t]{2}{*}{ Female CEO } & -0.0378 & & -0.1547 & \\
\hline & 0.0407 & & 0.1329 & \\
\hline Industry dummies & yes & & yes & \\
\hline Nobs. & 3,057 & & 2,956 & \\
\hline Pseudo R2 & 0.1576 & & 0.1643 & \\
\hline
\end{tabular}

Notes: Estimated from data from the Survey of Corporate Management and Economic Policy (RIETI) linked with the Basic Survey of Japanese Business Structure and Activities METI). Probit and Tobit estimates with robust standard errors in parentheses. ${ }^{* * *}$, **, and * indicate statistical significance at the $1 \%, 5 \%$, and $10 \%$ levels, respectively.

Table 5 Background of Male/Female CEOs

\begin{tabular}{|l|r|r|}
\hline \multicolumn{1}{c|}{ Background } & (1) Male CEO & (2) Female CEO \\
\hline Employee & $18.8 \%$ & $9.3 \%$ \\
\hline Founder & $10.0 \%$ & $0.0 \%{ }^{* *}$ \\
\hline Founder's family & $40.3 \%$ & $74.4 \%$ \\
\hline Others & $31.0 \%$ & $16.3 \%$ \\
\hline
\end{tabular}

Notes: The figures are calculated from the Survey of Corporate Management and Economic Policy (RIETI). ***, **, and * indicate the statistically significant differences between male and female CEOs at the $1 \%, 5 \%$, and $10 \%$ level, respectively. "Others" are the sum of "parent company", “financial institution”, and “others.” 
Table 6 Distribution of the Number of Foreign Directors

\begin{tabular}{|l|r|r}
\hline & Companies & $\%$ \\
\hline 0 & 3,349 & $98.7 \%$ \\
\hline 1 & 16 & $0.5 \%$ \\
\hline 3 & 12 & $0.4 \%$ \\
\hline 4 & 9 & $0.3 \%$ \\
\hline 5 or more & 2 & $0.1 \%$ \\
\hline Total & 4 & $0.1 \%$ \\
\hline
\end{tabular}

Note: The figures are calculated from the Survey of Corporate Management and Economic Policy (RIETI).

Table 7 Foreign Directors and Company characteristics

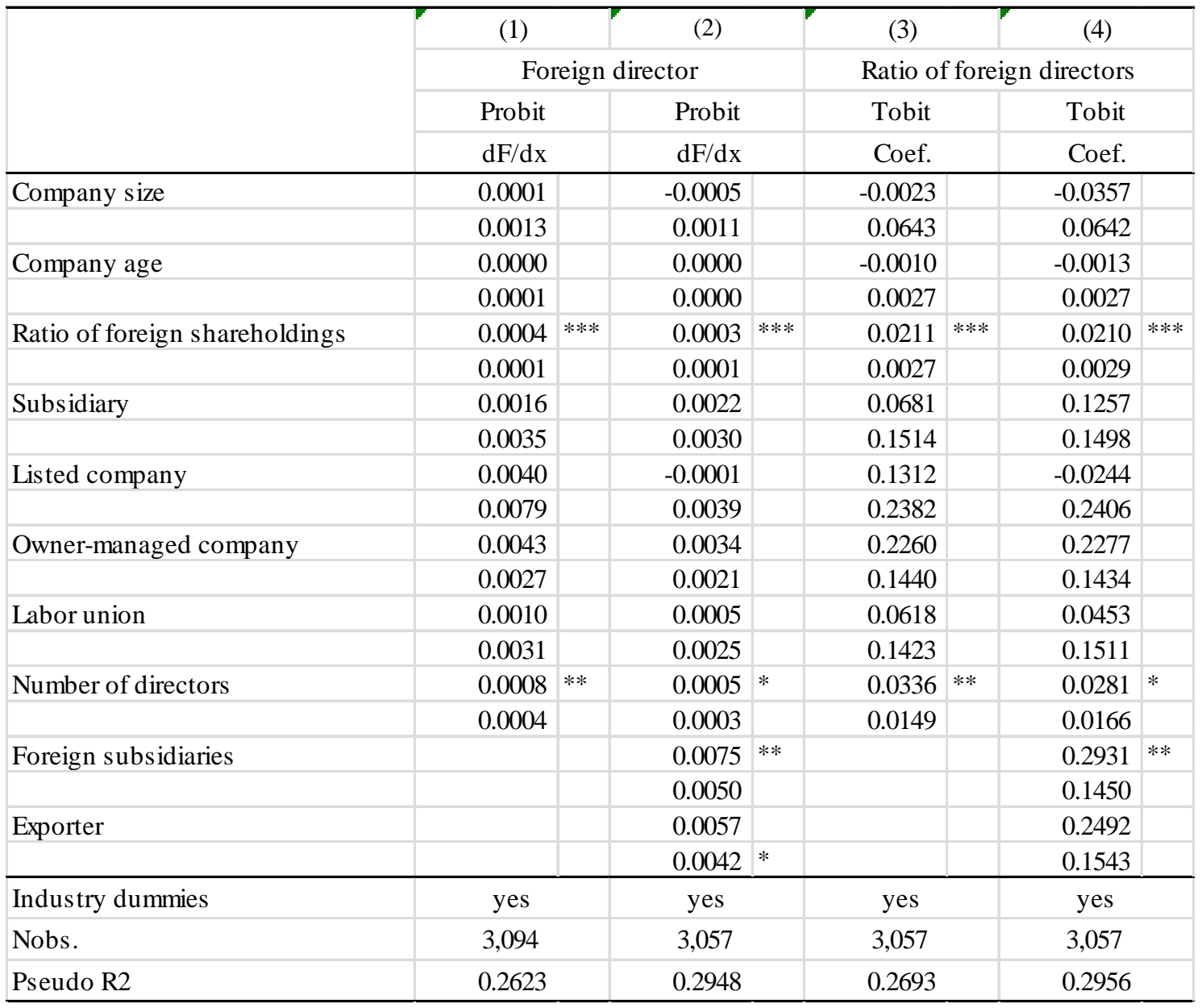

Notes: Estimated from data from the Survey of Corporate Management and Economic Policy (RIETI) linked with the Basic Survey of Japanese Business Structure and Activities METI). Probit and Tobit estimates with robust standard errors in parentheses. $* * *, * *$, and $*$ indicate statistical significance at the $1 \%, 5 \%$, and $10 \%$ levels, respectively. 